\title{
Peripheral Nervous System Part
}

National Cancer Institute

\section{Source}

National Cancer Institute. Peripheral Nervous System Part. NCI Thesaurus. Code C33968.

Any component of the nervous system that is external to the brain and spinal cord. 